Çukurova Üniversitesi Eğitim Fakültesi Dergisi

Vol: 50 Numb: 2 Page: 649-662

https://dergipark.org.tr/tr/pub/cuefd

\title{
Investigating L2 Motivational Self System in the Turkish University Context \\ Simla COURSE ${ }^{\mathrm{a}^{*}}$ (ORCID ID - 0000-0003-2977-853X) \\ Fatma Özlem SAKA ${ }^{\mathrm{b}}$ (ORCID ID - 0000-0003-0647-9983)
}

${ }^{a}$ Akdeniz Üniversitesi, Eğitim Fakültesi, Antalya/Türkiye

${ }^{\mathrm{b}}$ Akdeniz Üniversitesi, Eğitim Fakültesi, Antalya/Türkiye

CrossMark

\section{Article Info}

DOI: $10.14812 / c u f e j .955225$

Article history:

Received 21.06.21

Revised 24.08.21

Accepted 07.09.21

Keywords:

L2 motivational self system,

language learning motivation,

English as a foreign language.

\section{Abstract}

This research explores how well L2 motivational self systems explain language learning motivation of university students in the Turkish context. To this end, data were collected from 668 university students in a state university in Turkey using a 51-item questionnaire and semi-structured interviews in this mixed methods research. The data from both the questionnaire and the interview indicate an overwhelming impact of language learning experience on the learners' motivation to learn English as a foreign language as opposed to their ideal L2 selves or ought-to L2 selves. The findings about the relationship among the components of $L 2$ motivational self systems are in line with the results of the previous research, lending support to the framework of L2 motivational self systems. Finally, the results suggest that learners' motivation is a dynamic system, changing and evolving over time. The study has implications for language teachers, curriculum designers as well as further research in language learning motivation.

\begin{tabular}{|c|c|}
\hline \multicolumn{2}{|c|}{ Makale Bilgisi } \\
\hline \multicolumn{2}{|c|}{ DOI: 10.14812/cufej.955225 } \\
\hline \multicolumn{2}{|c|}{ Makale Geçmişi: } \\
\hline Geliş & 21.06 .21 \\
\hline Düzeltme & 24.08 .21 \\
\hline Kabul & 07.09 .21 \\
\hline
\end{tabular}

Anahtar Kelimeler:

İkinci dil benlik sistemi, dil öğrenme motivasyonu, yabancı dil olarak İngilizce.

\section{Bağlamında İkinci Dil Motivasyon Benlik}

\section{Sisteminin İncelenmesi}

\section{Öz}

Bu çalışmanın amacı, ikinci dil motivasyon benlik sistemlerinin, yabancı dil öğrenme motivasyonunu Türkiye üniversite bağlamında ne kadar açıkladığını araştırmaktır. Bu amaca yönelik olarak, Türkiye'deki bir devlet üniversitesinde İngilizce öğrenimi görmekte olan 668 üniversite öğrencisinden karma araştırma yöntemi kullanılarak 51 maddelik bir anket ve yarı yapılandırmacı mülakat ile veri toplanmıştır. Hem anket hem de mülakattan elde edilen veri öğrencilerin yabancı dil öğrenme motivasyonlarında ideal ikinci dil benliği ve zorunlu ikinci dil benliği yerine, ikinci dil motivasyon benlik sisteminin üç ayağından biri olan yabancı dil öğrenme deneyimlerinin çok büyük etkisi olduğunu göstermiştir. Mülakatlardan elde edilen nitel veri, bu çalışmada dil öğrenme motivasyonunda en çok yabancı dil öğretmenlerinin etkili olduğunu göstermiştir. Bu etkinin iki șekilde sağlandığı görülmüștür; öğretmenlerin öğrencilerle kurdukları bağ ve öğrencilerin öğretmenlere atfettikleri olumlu bireysel nitelikler vasıtasıyla. İkinci dil motivasyon benlik sisteminin öğelerinin arasındaki ilişki ile ilgili bulgular ise bundan önceki çalışmaların sonuçları ile aynı doğrultudadır ve araçsal teşviğin ideal ikinci dil benliğini tahmin ettiği bulunmuştur. Benzer şekilde zorunlu ikinci dil benliği ve araçsal önlem arasında kuvvetli korelasyon bulunmuştur. Ancak İngilizce öğrenmeye yönelik tutumları en çok bütünleşme ve ideal ikinci dil benliği tahmin ettiği görülmüştür. Son olarak, bulgular öğrencilerin motivasyonlarının zamanla değişen ve evrilen dinamik bir sistem olduğunu ortaya koymaktadır. 


\section{Introduction}

Early research on motivation started in the first half of $20^{\text {th }}$ century and since then it has not lost momentum. Motivation is a variable that is greatly correlated to achievement. As a result, there is a plethora of research aiming to get a better, clearer understanding of the complex matter of motivation in learning, and more specifically in L2 learning. Early research adopts the view that motivation is a strictly biological response to stimulus, while cognitive and social approaches recognize learners as complex beings and aim to get a better understanding of learners' past experiences, future expectations, goals, anxiety, self-efficacy and attitudes to the target language and L2 culture (Weiner, 1990; Gardner, 1985). More recently, however, learners are recognised as agents capable of meaning making, individuals "with an identity, a personality, a unique history" (Ushioda, 2009, p.220). Thus L2 motivation research, in its quest to get a better insight into language learning motivation, has turned its attention to the learners' self-systems in its exploration of learners as agents. This study too aims to build on our understanding of language learning motivation by investigating the role EFL learners' self systems in their motivation to learn English. To this end, first we will review research on L2 Motivational Self Systems (L2MSS) then we will report our research investigating L2MSS in the Turkish university context.

Exploring learners' perceptions of their future possible selves in L2 learning and Higgins' theory of self-discrepancy, Dörnyei (2014) proposes L2MSS. This approach is based on the premise that humans have a sense of their "current selves" and conceptualisations of their future possible selves (Markus \& Nurius 1986, p. 954). These are visions of what individuals would like to become in the future, i.e. ideal self, and their visions of what they are expected to become by significant others, obligations, and so on, i.e. their ought to self (Dörnyei, 2009). Higgins proposes in self-discrepancy theory that, if one's perception of their current self does not match their future self guides, they are likely to extend effort to move their current self closer to their future self guides, engaging in motivated behaviour (Dörnyei, 2009).

L2MSS is a tripartite model which builds on the construct of future possible selves and proposes a model for language learning. In this model, learners' future self guides, i.e., their ideal L2 self (henceforth IL2S), and ought-to L2 self (henceforth OL2S) together with their L2 learning experience (henceforth LE), influence their motivated learning behaviour (Dörnyei, 2009; Dörnyei, 2014). Both IL2S and OL2S are one's vision of themselves in the future regarding L2. IL2S refers to "the L2 specific facet of one's 'ideal self'" while OL2S self refers to the vision of themselves that they believe they ought-to become as part of responsibilities, obligations, expectations from others to avoid undesirable consequences (Dörnyei, 2009, p. 29). Building on Gardner's socio-educational model, Dörnyei (2009) refers to the motive to avoid undesirable outcomes as instrumentality prevention. Similarly, any motive related to possible gains as a result of the learning process is connected to one's future ideal self and is labeled instrumentality promotion (ibid.). Future self-guides are not static but highly dynamic and can change over time (Mercer, 2011; Dörnyei, 2009). LE, however, draws on the learners' past and current language learning environment including classroom practices, the curriculum, the teacher, etc. (Dörnyei, 2009). It should be noted here that, aiming to understand learners' self concepts, Mercer proposes "individual self, the relational self and the collective self" following Sedikides and Brewer's model of selfconcept (2014, p. 53). These are: the perception of oneself as different from the others; perception of oneself in the light of the views of significant others and perception of oneself guided by identification with a larger group or community, respectively (Mercer, 2014).

However, as some language learners and teachers will agree, it is not uncommon to have a future image of oneself as a proficient L2 speaker yet to not take any actions to realise this vision in the foreseeable future. Dörnyei proposes that for IL2S and OL2S to provide an impetus for learning, learners should have an elaborate and vivid image of their future selves; these future self-guides should be plausible; they should be activated to become part of the learners' "working self-concept"; IL2S and OL2S should not clash with each other; the learners should have access to "procedural strategies" to attain these future self-guides; and the possible self should be "offset by a feared (possible) self" 
(Dörnyei, 2009, pp. 19-21). Peker (2020) remarks that moving towards IL2S means moving away from the feared self.

As stated above, there is a growing number of studies investigating L2MSS in various contexts to explore to what extent it explains motivated language learning behavior and how its components relate to each other as a tripartite model. Findings of these studies suggest that L2MSS can help us understand motivation in a wide array of contexts. One recurring finding reported from a number of contexts is the strong contribution of LE and IL2S to motivated learning behaviour (Huang, Hsu \& Chen, 2015; Papi \& Teimouri, 2012; Li, 2014; Islam, Lamb \& Chambers, 2013; Lamb, 2012; Ueki \& Takeuchi, 2013; Moskovsky et. al., 2016; Yetkin \& Ekin, 2012; Altıner, 2018). In fact, LE appears to be the strongest predictor of motivated learning behaviour repeatedly in a number of studies (Papi, 2010; Papi \& Teimouri, 2012; Kormos \& Csizer, 2008; Li, 2014; Islam, Lamb \& Chambers, 2013; Lamb, 2012; Yetkin \& Ekin, 2012). Research also provides some insight into the relationship between motivation and LE, although LE needs to be researched further. By and Laohawiriyanon (2019), for example, found that lack of novelty and variation in teaching, and lack of communication in L2 were demotivating for language learners. Nakamura (2016) found that teachers played a prominent role on motivating learners. The teachers were regarded either as role models or they adopted a parental role "encouraging (the learners)" (ibid., p.9).

However, findings regarding OL2S do not seem as straightforward. OL2S is reported to either contribute in a limited capacity or not at all to motivated learning behaviour in some studies (Csizer \& Kormos, 2009; Li, 2014; Islam, Lamb \& Chambers; Lamb, 2012). Yet, in other studies it appears as a strong predictor of motivated learning behaviour (Papi, 2010; Huang, Hsu \& Chen, 2015; Ueki \& Takeuchi; Yetkin \& Ekin). It is suggested that OL2S plays an important role in predicting motivated behaviour in Asian contexts (Taguchi et.al., 2009; Ueki \& Takeuchi, 2013). However, other studies in Asian contexts, contradict this claim (Papi \& Teimouri, 2012; Li, 2014). Therefore, there is a need for further research reporting from a variety of contexts to build on our understanding of L2MSS. Furthermore, although OL2S may not contribute directly to motivated learning behaviour, it can have an indirect impact through instrumentality prevention or family influence. Papi and Teimouri (2012) report, for example, family influence as a predictor of motivated learning behaviour for high school learners in the Iranian context. Similarly, although IL2S does not explain motivated behaviour in Li's study (2014), instrumentality promotion does. In fact, instrumentality promotion has repeatedly been found to have high correlation with IL2S while instrumentality prevention has high correlation with OL2S (Islam et. al., 2013; Taguchi, Magid \& Papi, 2009; Papi \& Teimouri, 2012; Busse \& Williams, 2010). There is also a correlation between IL2S and integrativeness in some contexts Kormos \& Csizer, 2008; Taguchi, Magid \& Papi, 2009). It should be noted that motivated learning behaviour also contributes to IL2S, indicating a dynamic interplay between these two constructs (Munezane, 2013).

In the Turkish context, L2MSS were investigated with regard to the correlation among the tripartite model's components (Arslan \& Çiftçi, 2021; Ceyhan-Bingöl, Akarslan \& Özkan, 2020) or correlation of L2MSS with willingness to communicate (Öz \& Bursalı, 2018). Ceyhan-Bingöl et. al. (2020) report that for university level learners of English, no components of L2MSS were found to be "dominant" but that instrumentality promotion was central to the participants' motivation. Arslan and Çiftçi (2021) investigated L2MSS of secondary school pupils. Their findings indicate a strong correlation between IL2S and LE and between intended learning effort and IL2S. Yetkin and Ekin (2012), on the other hand, found that LE and OL2S were the strongest predictors of intended learning effort followed by IL2S for the secondary school learners. They also found that intended learning effort tended to decrease over years. Kim (2012) reports a similar finding from the Korean context where the motivation of L2 learners gradually decrease in formal education. As such decrease starts as early as age 11-12 in Yetkin and Ekin's study (2012), this finding needs to be investigated further to understand the exact role of LE on L2MSS.

As reviewed above, studies looking into L2MSS of university students in the Turkish context investigated how L2MSS correlated with the students' majors (Ceyhan-Bingöl et. al., 2020) or with the students' willingness to communicate (Öz \& Bursalı, 2018.) Although there are studies exploring to what 
extent L2MSS explains language learning motivation in the Turkish context, they are conducted in the secondary school context (Yetkin \& Ekin, 2012; Arslan \& Çiftçi, 2021). In addition, as Moskovsky et. al. remark (2016), the majority of research on L2MSS report quantitative findings and the number of studies employing mixed methods research to provide in-depth data is limited in number. Thus, this research aims to investigate how well L2MSS explain L2 motivation in the Turkish university context to help build on our understanding of L2MSS as a model, using mixed methods research, as will be discussed in detail below.

\section{Method}

\section{Research Model}

This research uses mixed methods research design. Mixed methods research is a study in which both qualitative and quantitative data are collected and analysed (Dörnyei, 2007; Leech \& Onwuegbuzie, 2009; Schoonenboom \& Johnson, 2017). This design can offer a "fuller understanding of a target phenomenon" (Dörnyei , 2007, p. 164) by providing data on causality and generalisability, which is available through quantitative data; at the same time as providing rich, in-depth data from individual learners or contexts, which is typically available via qualitative data. One function of mixed methods research is to combine both sets of data to offer a more elaborate, clear and comprehensive picture than one set of data would on its own. This is also called the "complementarity" purpose of mixed methods research design (Dörnyei, 2007; Schoonenboom \& Johnson, 2017). Similarly, this study explores both causal relationships L2MSS have with language learner motivation and individual learners' years-long language learning journey in relation to their L2MSS. Individual learners' language learning journeys are expected to provide rich and in depth data to complement the generalisable and rather compact data about causality. Complementarity is the main reason in selection of this design for this study. Accordingly, in this research quantitative data are collected and analysed to investigate the causality of L2MSS, and qualitative data are collected and analysed to explore how L2MSS components influence learners' motivation to learn English in their language learning experience.

Thus, this study aims to answer the following questions:

1. How well does the tripartite model of L2MSS explain L2 motivation in the Turkish tertiary context?

2. What is the relationship between the three main components of L2MSS?

3. How do the components of L2MSS shape EFL learners' motivation?

The first two questions seek to answer causality; thus, a questionnaire and statistical analysis are used to analyse the data. The last research question seeks to understand how L2MSS components influence learners' motivation; thus, a semi-structured interview is used to collect in depth- data and data are analysed accordingly, as discussed below.

\section{Study Group}

Data were collected in the 2017-2018 academic year from 668 language learners enrolled at a state university in Turkey. The participants for the questionnaire were selected using convenience sampling, based on ease of access and agreement to volunteer (Dörnyei, 2007). Following the questionnaire, 18 participants were interviewed. Purposive sampling was used for the interview. The interviewees were selected based on their responses to the questionnaire to represent participants with high, moderate and low scores for intended learning effort. The participants, aged 18-23, were studying engineering, pre-school education, science education, English language teaching, science and social studies at the time of the study. Their proficiency levels were between A1-B2. Of the 668 students that participated in this study, 103 were A1 level, 292 were A2 level, 170 were B1 level and 103 were B2 level, as certified by the language school of the university they were enrolled in. All A1 level participants were enrolled in their departments and were taking compulsory departmental English courses. A2 level participants were studying a year-long intensive English course at the university's language school and B1 and B2 level 
learners were English language teaching students studying in the language school and in their departments, respectively.

All participants were volunteers who were given detailed information about the aim of the research, their rights as participants and the data collection and analysis processes in both oral and written forms. They all gave consent to participating in the study. No personal information was collected from the participants except for the names and email addresses of the volunteers to be interviewed. All the participants were reassured about anonymity and confidentiality. Thus, the interviewees' names presented in this study are pseudonyms.

\section{Data Collection Tools}

As discussed above, this is a mixed methods research, in which both a questionnaire and a semistructured interview are used to collect data. The questionnaire, adapted from Taguchi et. al. (2009), was used to collect data to investigate the relationship between L2MSS and learners' motivation and the relationship between the three main components of L2MSS. The questionnaire was first translated into Turkish and piloted with 54 university students. The students were asked for suggestions, problems or ambiguities in the questionnaire's wording. No problems were reported and the questionnaire was administered. It took 10-15 minutes to complete the questionnaire. After the preliminary analysis of the questionnaire, 18 volunteering participants were interviewed to collect in depth data regarding the influence of L2MSS components on learners' motivation. The semi-structured interviews lasted 389.44 minutes in total, each interview averaging at 21.63 minutes. The interview questions inquired about their IL2S, OL2S, and LE.

\section{Data Analysis}

Quantitative data were analysed using SPSS. Cronbach's Alpha was computed to investigate the reliability of the questionnaire and the motivational scales. Next, correlation and stepwise multiple regression analysis were done to investigate the relationship between components of L2MSS. The assumptions for the multiple regression of normality, multicollinearity, homoscedasticity and linearity were inspected and the data were not found to violate these assumptions. As shown on Table 2, the correlation between some variables were above .70, which can potentially be a threat to the assumption of multicollinearity. To check that this assumption is not violated, multicollinearity diagnostic tests were run and the VIF values were found to be well below the conservative cut off point of $>5$, as presented in Tables 3-6.

Prior to designing the semi-structured interviews, review of L2MSS literature was carried out for content and construct validity. Next the interviews were conducted and transcribed. Then two researchers looked for themes and patterns emerging from the interviews and coded the data independently for intercoder reliability. The analysis of both researchers coincided. Next, relevant themes and patterns were grouped together. For example, the themes of "teacher", "games", "grammar activities" were all grouped under the category "learning experience". Finally the themes and categories were tabulated to give an overview of the learners' accounts.

\section{Findings}

First, Cronbach $\alpha$ for the quantitative data were computed and the results of the reliability analysis are presented in Table 1. Although the acceptable value of Cronbach $\alpha$ is $>.7$, both instrumentality prevention and integrativeness are retained for further analysis in this study. Instrumentality prevention scale was retained in analysis as it was close to .7 mark. Integrativeness is also retained for further analysis as a small number of questionnaire items is expected to return a low $\alpha$ value. However, due to the low Cronbach value of this construct, the results should be interpreted with caution. 
COURSE \& SAKA - Çukurova Üniversitesi Eğitim Fakültesi Dergisi, 50(2), 2021, 649-662

Table 1.

Descriptives

\begin{tabular}{cccccc}
\hline Motivational scales & $\begin{array}{c}\text { Number } \\
\text { of items }\end{array}$ & $\mathbf{N}$ & Mean & $\begin{array}{c}\text { Standard } \\
\text { Deviation }\end{array}$ & Cronbach $\boldsymbol{\alpha}$ \\
\hline Questionnaire & 51 & 668 & - & - & .944 \\
\hline Intended learning effort & 5 & 668 & 3.767 & .92338 & .751 \\
\hline OL2S & 5 & 668 & 4.574 & 1.1481 & .883 \\
\hline Attitudes to learning English & 7 & 668 & 3.408 & .9952 & .757 \\
\hline Instrumentality promotion & 4 & 668 & 3.897 & 1.2815 & .858 \\
\hline Instrumentality prevention & 7 & 668 & 5.005 & .85282 & .812 \\
\hline Family Influence & 6 & 668 & 3.716 & 1.0441 & .685 \\
\hline Attitudes to the target community & 6 & 668 & 3.767 & .92338 & .719 \\
\hline Integrativeness & 4 & 668 & 4.788 & 1.0976 & .836 \\
\hline Cultural interest & 3 & 668 & 4.374 & 1.1105 & .581 \\
\hline
\end{tabular}

The results of the correlation analysis (Table 2) show that intended learning effort correlates strongly only with attitudes to learning English, suggesting an interaction between intended learning effort and learning experience. Intended learning effort is also found to moderately correlate with IL2S, attitudes to target community and integrativeness. The strongest correlation found in this study, however, is between instrumentality promotion and IL2S, which is not surprising considering the established relationship between these constructs as reviewed above. IL2S is also strongly correlated with attitudes to target community and cultural interest. As expected, OL2S correlates strongly with instrumentality prevention and family influence. In addition to these, the only other strong correlations found in this study are between attitudes to target community and instrumentality promotion; and between integrativeness and cultural interest.

Table 2.

Correlations

\begin{tabular}{|c|c|c|c|c|c|c|c|c|c|c|}
\hline & 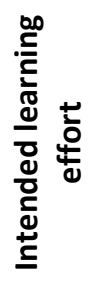 & $\stackrel{\simeq}{=}$ & $\begin{array}{l}\text { సี } \\
\text { ठ }\end{array}$ & 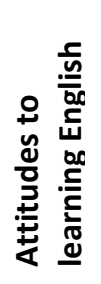 & 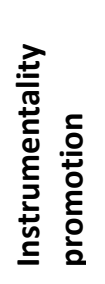 & 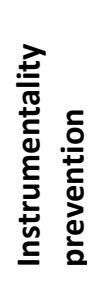 & 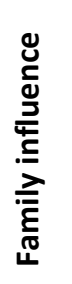 & 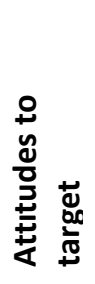 & 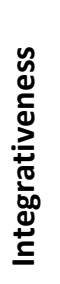 & 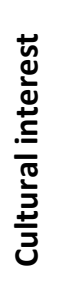 \\
\hline Intended learning effort & 1 & & & & & & & & & \\
\hline \multirow[t]{2}{*}{ IL2S } & .55 & 1 & & & & & & & & \\
\hline & $0 * *$ & & & & & & & & & \\
\hline \multirow[t]{2}{*}{ OL2S } & .37 & .32 & 1 & & & & & & & \\
\hline & 8 & $0 * *$ & & & & & & & & \\
\hline \multirow[t]{2}{*}{ Attitudes to learning English } & .71 & .57 & .33 & 1 & & & & & & \\
\hline & $9 * *$ & $1^{* *}$ & $3^{* *}$ & & & & & & & \\
\hline \multirow[t]{2}{*}{ Instrumentality promotion } & .46 & .75 & .45 & .43 & 1 & & & & & \\
\hline & $7^{* *}$ & $7^{* *}$ & $2^{* *}$ & $7^{* *}$ & & & & & & \\
\hline \multirow[t]{2}{*}{ Instrumentality prevention } & .14 & .16 & .60 & .10 & .37 & 1 & & & & \\
\hline & $4^{* *}$ & $6 * *$ & $6 * *$ & $0 * *$ & $2^{* *}$ & & & & & \\
\hline \multirow[t]{2}{*}{ Family influence } & .32 & .34 & .69 & .26 & .49 & .57 & 1 & & & \\
\hline & $6 * *$ & $2^{* *}$ & $3^{* *}$ & $3^{* *}$ & $3^{* *}$ & $3^{* *}$ & & & & \\
\hline \multirow[t]{2}{*}{ Attıtudes to target community } & .53 & .68 & .34 & .55 & .67 & .20 & .35 & 1 & & \\
\hline & $1 * *$ & $7^{* *}$ & $7^{* *}$ & $8^{* *}$ & $5^{* *}$ & $7^{* *}$ & $3 * *$ & & & \\
\hline Integrativeness & .53 & .57 & .43 & .62 & .58 & 248 & .40 & .70 & 1 & \\
\hline
\end{tabular}


COURSE \& SAKA - Çukurova Üniversitesi Eğitim Fakültesi Dergisi, 50(2), 2021, 649-662

\begin{tabular}{rccccccccccc}
\hline & $7 * *$ & $9 * *$ & $0^{* *}$ & $5^{* *}$ & $9^{* *}$ & $* *$ & $8^{* *}$ & $3^{* *}$ & & \\
\hline Cultural interest & .46 & .63 & .19 & .51 & .58 & .10 & .26 & .69 & .61 & 1 \\
& $6 * *$ & $5^{* *}$ & $0^{* *}$ & $6^{* *}$ & $2^{* *}$ & $4^{* *}$ & $5^{* *}$ & $5^{* *}$ & $4^{* *}$ & \\
\hline
\end{tabular}

**Correlation is significant at the 0.01 level (2-tailed).

Bonferroni adjusted $\mathrm{p}$ value to .05

To investigate which motivational scales contributed to the participants' intended effort, stepwise multiple regression analysis was carried out. The final model accounts for the $56 \%$ of the variance in the intended learning effort of the participants and shows that out of the four variables that predict intended learning effort, the first three are the components of L2MSS. In other words, in the final model, attitudes to learning English, the scale inquiring LE, IL2S and OL2S are all found to predict intended learning effort. It is important to note, however, that LE is found to be the strongest predictor of intended learning effort by far. IL2S and OL2S predict intended learning effort more modestly (Table 3).

Table 3.

Results of the Multiple Regression Analysis of the Motivational Scales with Intended Learning Effort as the Dependent Variable

\begin{tabular}{lllllll}
\hline \multicolumn{1}{c}{ Variable } & Final model & & & & \\
\hline \multicolumn{1}{c}{$\mathbf{B}$} & SE B & $\boldsymbol{\beta}$ & $\mathbf{t}$ & Tolerance & VIF \\
\hline Attitudes to learning English & .426 & .025 & $.553^{* *}$ & 16.812 & .608 & 1.644 \\
\hline IL2S & .118 & .032 & $.137^{* *}$ & 3.673 & .475 & 2.104 \\
\hline OL2S & .119 & .028 & $.119^{* *}$ & 4.288 & .847 & 1.180 \\
\hline Attitudes to L2 culture and community & .078 & .033 & $.087^{* *}$ & 2.346 & .478 & 2.091 \\
\hline Adjusted R2 & $.561^{* *}$ & & & & & \\
\hline F for change in R2 & $5.503^{*}$ & & & & & \\
\hline
\end{tabular}

$* p<.05$.

$* * \mathrm{p}<.001$.

Next, multiple regression analysis was conducted to find out the motivational scales that contribute to the participants' IL2S. The final model of multiple regression analysis explains an impressive $68 \%$ of the variance in IL2S (Table 4). The final model shows that the contribution of instrumentality promotion to IL2S is considerably stronger than the remaining four variables in the model, which is to be expected in the light of the studies reviewed above. Attitudes to learning English, cultural interest and attitudes to L2 culture and community predict IL2S much more moderately while instrumentality prevention predicts IL2S negatively. Considering the relationship between instrumentality prevention and OL2S, as presented in Table 5, this finding is not unexpected either.

Table 4.

Results of the Multiple Regression Analysis of the Motivational Scales with Ideal L2 Self as the Dependent Variable

\begin{tabular}{|c|c|c|c|c|c|c|}
\hline \multicolumn{5}{|c|}{ Final model } & \multirow[b]{2}{*}{ Tolerance } & \multirow[b]{2}{*}{ VIF } \\
\hline Variable & B & SE B & $\boldsymbol{\beta}$ & $\mathbf{t}$ & & \\
\hline Instrumentality promotion & .712 & .044 & $.529 * *$ & 16.341 & .457 & 2.188 \\
\hline Attitudes to learning English & .178 & .024 & $.198^{* *}$ & 7.332 & .654 & 1.528 \\
\hline Attitudes to L2 culture and community & .151 & .037 & $.145^{* *}$ & 4.061 & .377 & 2.652 \\
\hline Cultural interest & .142 & .034 & $.135^{* *}$ & 4.205 & .467 & 2.143 \\
\hline Instrumentality prevention & -.105 & 0.26 & $-.095 * *$ & -3.991 & .842 & 1.188 \\
\hline Adjusted R2 & $.680 * *$ & & & & & \\
\hline
\end{tabular}


$* \mathrm{p}<.05$

$* * \mathrm{p}<.001$.

Below, Table 5 shows that family influence, instrumentality prevention, attitudes to learning English, integrativeness and instrumentality promotion predict OL2S and this model explains $59 \%$ of the variance. The findings show that the strongest predictor of OL2S is family influence, followed by instrumentality prevention, which is in line with the studies reviewed above. Attitudes to learning English are found to be the third strongest positive predictor of OL2S. Interestingly, cultural interest negatively predicts OL2S while integrativeness positively predicts it. This finding can be due to an understanding that if one is interested in L2 culture or the target language, they might feel obliged to learn the language. If they are interested in the $\mathrm{L} 2$ music, films or books, this may also strictly remain as an interest in arts, without any connection to a feeling of obligation.

Table 5.

Results of the Multiple Regression Analysis of the Motivational Scales with Ought-to L2 Self as the Dependent Variable

\begin{tabular}{|c|c|c|c|c|c|c|}
\hline \multicolumn{7}{|c|}{ Final model } \\
\hline Variable & B & SE B & $\boldsymbol{\beta}$ & $\mathbf{t}$ & Tolerance & VIF \\
\hline Family influence & .465 & .036 & $.431^{* *}$ & 13.051 & .562 & 1.778 \\
\hline Instrumentality prevention & .285 & .030 & $.299 * *$ & 9.638 & .641 & 1.561 \\
\hline Cultural interest & -.149 & .032 & $-.164 * *$ & -4.733 & .515 & 1.943 \\
\hline Attitudes to learning English & .119 & .025 & $.154^{* *}$ & 4.707 & .576 & 1.736 \\
\hline Integrativeness & .127 & .034 & $.142 * *$ & 3.754 & .430 & 2.326 \\
\hline Instrumentality promotion & .084 & .042 & $.072 *$ & 2.020 & .485 & 2.064 \\
\hline Adjusted R2 & $.590 * *$ & & & & & \\
\hline $\mathrm{F}$ for change in $\mathrm{R} 2$ & $4.081^{*}$ & & & & & \\
\hline
\end{tabular}

$* \mathrm{p}<.05$.

$* * p<.001$.

Finally, integrativeness and IL2S are both found to be strong predictors of attitudes to LE (Table 6). Interestingly, both instrumental promotion and instrumental prevention are found to negatively predict attitudes to LE. This finding was not expected considering the strong relationship between IL2S and instrumentality promotion. The contribution of OL2S is found to be weaker than that of IL2S. The unexpectedly strong contribution of integrativeness to attitudes to LE can be better understood with interview data, as will be discussed below.

Table 6.

Results of the Multiple Regression Analysis of the Motivational Scales with Attitudes to Learning English as the Dependent Variable

\begin{tabular}{|c|c|c|c|c|c|c|}
\hline \multicolumn{7}{|c|}{ Final model } \\
\hline Variable & B & SE B & $\boldsymbol{\beta}$ & $\mathbf{t}$ & Tolerance & VIF \\
\hline Integrativeness & 462 & .046 & $400 * *$ & 10.001 & .486 & 2.057 \\
\hline Ideal L2 self & .399 & .052 & $.357^{* *}$ & 7.617 & .354 & 2.828 \\
\hline Attitudes to target community & .271 & .056 & $.232 * *$ & 4.858 & .378 & 2.643 \\
\hline Instrumentality promotion & -.266 & .072 & $-177^{* *}$ & -3.675 & .334 & 2.994 \\
\hline Ought-to L2 self & .216 & .050 & $.168 * *$ & 4.357 & .526 & 1.902 \\
\hline Cultural interest & .148 & .047 & $.126^{*}$ & 3.125 & .480 & 2.083 \\
\hline Instrumentality prevention & -.131 & .044 & $-.107^{*}$ & -2.946 & .593 & 1.686 \\
\hline Adjusted R2 & $.482 * *$ & & & & & \\
\hline $\mathrm{F}$ for change in $\mathrm{R} 2$ & $8.679 *$ & & & & & \\
\hline
\end{tabular}


$* \mathrm{p}<.01$.

$* * \mathrm{p}<.001$.

To get rich, in depth data regarding L2MSS of the participants, 18 participants were interviewed. The participants were asked about their language learning journey, what motivated (or demotivated) them to learn English, their LE and future possible selves. Similar to the quantitative data, the interview data also indicate LE as the most influential factor in the interviewees' motivation. Ten interviewees reportedly were motivated by their LE, particularly their teachers, while three were demotivated by their LE. Out of the ten interviewees that pointed their teachers as motivating, eight reported that their teachers were "affectionate", "kind", and "caring", who "valued" their learners and "showed interest in them". Thus, it was the rapport the teachers built with the interviewees that they found motivating:

"I loved my primary school teacher. I would study hard just for her... She showed interest in me. Everybody likes receiving interest from others" (Ada)

"(My English teacher) was a very caring, kind woman. It was then that I liked the (English) lessons. I tried hard to learn English, I did my best, I studied, I bought books in English, I studied from (extracurricular) course books." (Zuhal)

Two interviewees, on the other hand, reported that their teachers were important in motivating them to learn English not because of any rapport they built with the interviewees but because of the individual qualities these teachers possessed:

"The first thing that stroke me about my English teacher was the way she looked... her posture, the way she talked, but mostly her pronunciation... She was sure of herself. She could express herself better than other teachers. And she could speak a foreign language." (Meral)

"My arts teacher really motivated me to learn English. She was very different than other teachers... She spoke more than one foreign language and told us about these languages. Because she was a fun teacher, I thought speaking English is fun too." (Hale)

LE also resulted in low motivation for three interviewees. Both Merve and Emel stated that they studied the same things year after year without progress in their learning:

“I really didn't like English at all... I've been studying English for 12 years now... I'm really sorry for complaining but I'm so fed up of it. Why do we study tenses all the time? We always study tenses and I keep thinking is this continuous or past? Is it verb two or three? I know what they all are; but I can't speak English. A tourist asked me something in English the other day and all I could say was 'I don't know'; the only thing I know how to say in English." (Merve)

“(Enrolling at an intensive English course at university) would be a waste of time... because I've 12 years of English learning experience. I know what the teachers do. It's just grammar. There's no practicing (speaking)... You can only learn a foreign language through being exposed to it really, not by just learning grammar. But we only focus on grammar... I'm studying at university but unfortunately I'm still studying A1 level English. This is sad really... We wasted all this time and we still learn the same things we learned in primary school... There is no progress." (Emel)

Peri also reported demotivation in her LE. However, prior to her formal education, she was intrigued by English language because she lived in a small touristic town and she would hear tourists speak in English. She liked hearing it; she was curious about the language. Unlike Merve and Emel, Peri eventually became motivated to learn English and at the time of the study she was studying to be an English teacher. Peri reported that despite her negative LE, she carried on learning English because she liked watching detective TV shows, which happened to be in English. She was also not too keen on the cultural and educational life of her "small hometown" and found that she liked "the lifestyles" of the people she watched on TV shows. However, in time, speaking English became a more integral part of her sense of self. She stated that now speaking English is important for her to understand human experience. She "likes listening to people, who have unique experiences." She is also interested in 
learning about art as she finds art too explains human experience. "Other people waste time online, but I read about art (in English)". Thus, English has become an important aspect of how she defines herself, someone who strives to understand humans through communication and art:

"(Speaking English) helps me improve the way I think, helps me see things from different perspectives... to understand the world." (Peri)

Peri also made frequent references to a feeling of being different from her peers for learning or speaking English. She reported a feeling of being different for watching TV shows in English when her friends "would watch children's TV in Turkish when (she) watched shows like Sherlock Holmes." Later in the interview she mentioned that she liked listening to people's stories in situations where "her peers would ignore these stories." English is relevant to this feeling of being different in her account. In other words, English is important for her individual self.

Integrative motive was influential for Meltem also. She "liked watching TV shows in English... liked the language... wanted to talk like (the characters in the TV shows)." She too was studying to be an English teacher at the time of the study and she reported that she believed speaking English would provide her with good job prospects. Job prospects, however, were not a concern for her when she started watching the TV shows or when she wanted to learn the language earlier in her life. This instrumental motive became important for her much later in her life, right before it was time to decide what to study at university.

Like Peri, Dilara's initial interest in English was also through hearing others communicate in it. She had friends who spoke English in her hometown. She could not understand them and she wanted to learn English to be able to "talk like them... to communicate with them. Because I couldn't communicate with them, I was feeling like they were on a different level than me" making a reference to her relational self. Similar to Peri, Dilara started watching TV shows in English. However, unlike Peri or Meltem, TV shows did not provide an integrative motive but a sense of achievement, competence for Dilara. She just "enjoys being able to understand English phrases, words in these TV shows." However, English is part of her IL2S: "I'd like to become a successful researcher... that's why English is important to me. And also because l'd like to travel abroad."

Cultural interest was the main reason for learning English for two interviewees: Leman and Erol. Leman liked reading English literature then she became intrigued by the British and American cultures:

“...while I was reading (British and American) novels, I was afraid that if I couldn't learn (English), I couldn't visit these countries. ... It was always the novels, literature (that motivated me)." (Leman)

Erol was interested in mythology and history of English speaking countries. Later on, his interest in playing online games helped develop an international posture for him:

"I like English because when I play online games, you have players from all countries. For example, you have a player from Japan and I don't speak Japanese. But I can use English as a common language." (Erol)

Integrative motive or cultural interest were important in these interviewees' motivation. However, they were not the sole motives. Peri now refers to her IL2S to explain why she is studying English. Meltem reports instrumental promotion motives and Erol has an international posture after realising that his initial interest in English mythology meant access to his online community.

This dynamic interplay of motivational systems is also evident in the responses of the interviewees who were initially motivated by their LE. One common theme that emerged from these participants' responses is high linguistic confidence:

"I liked English because I was good at it." (Ada)

"My classmates' English was not good in high school, but I was got at it." (Yelda)

"Then I saw that if I studied it, I could learn it. I had a talent for it." (Ruya) 
"I realised I had a talent for learning languages." (Seyfi)

Two interviewees expressed that their teachers increased their linguistic confidence by explicitly telling the interviewees that they had a talent for learning English. Two others expressed that their classmates told them they were good at learning English.

Another component of LE that reportedly increased learners' motivation was "unusual" and "new" classroom practices such as playing games, singing, colouring etc. However, LE alone does not explain these interviewees' motivation to learn English anymore. Meral, Hale, Seyfi, Okan and Sinem stated that they now valued learning English for getting to know other people's perspectives. Their responses did not only show an openness to other cultures but had deeper implications for these interviewees' sense of selves:

"There is something I really believe in and it is that in order for me to improve myself as an individual, I need to learn about other cultures and different people." (Okan)

"I used to watch science fiction shows and they showed me a very different way of thinking. And I value different ways of looking at things. I am learning English to get to know others." (Hale)

"In secondary school, I started following the world on the internet. (To learn) about the world, how people think. I mean, why is a particular country the way it is? That's why we come to this world really, to learn about the world and to learn about ourselves." (Seyfi)

Considering that all the interviewees are young adults, the emphasis on getting to know the world and themselves is not surprising. Nevertheless, these students find English essential for their ideal selves, i.e. individuals who have learned to appreciate other people's perspectives and who have developed a sense of who they are.

In the interviews, family influence was also inquired. All the interviewees stated that their families were supportive of their choices but that their families did not have any expectations regarding learning English. However, Peri and Ruya stated that their families encouraged them to spend more time studying other school subjects. Both interviewees chose to invest their time and effort into learning English. Therefore, they reported, they did not want to fail at something they chose themselves. Similarly, Meral and Yelda stated that they would be worried to disappoint themselves, not others, should they fail to learn English, something they enjoyed doing. Therefore, family influence was not an issue for these learners but their feared self was.

\section{Discussion \& Conclusion}

This research aimed to find out how well the tripartite model of L2MSS explains L2 motivation in the Turkish university context in order to build up on our understanding of L2MSS as a model. To this end, quantitative data were collected and multiple regression analysis was conducted to investigate the predictive power of L2MSS. The three components of L2MSS were found to explain $56 \%$ of variance in intended learning effort. Therefore, the results of this study support the findings of previous research, as reviewed above, that L2MSS is beneficial in understanding the language learning motivation. The results of the regression analysis also showed that LE was by far the strongest predictor of intended learning effort. Similarly, LE was found to be the strongest contributor to intended learning effort in a number of contexts, (Papi, 2010; Papi \& Teimouri, 2012; Kormos \& Csizer, 2008; Li, 2014; Islam, Lamb \& Chambers, 2013; Lamb, 2012; Yetkin \& Ekin, 2012). It should be noted that some studies in different contexts investigating L2MSS of university students report IL2S as a strong predictor of intended learning effort (Huang et. al., 2015; Moskovsky et. al., 2016) while others, report LE as the strongest predictor of intended learning effort (Kormos \& Csizer, 2008; Islam et. al. 2013; Papi \& Teimouri, 2012). In this research too, LE is found to be the strongest predictor of intended learning effort for university students.

Another aim of this study was to investigate the relationship among L2MSS components to understand this model better since contradicting results were reported regarding the components of 
L2MSS, as discussed above in detail. Thus, relationship between the three components of L2MSS was also investigated. Previously, Ceyhan-Bingöl et. al. (2020) found that no components of L2MSS was dominant in L2MSS in the Turkish university context while Arslan and Ciftci (2021) found a strong correlation between IL2S and intended learning effort in the Turkish context. The findings of this study, however, point that LE is by far the strongest predictor of motivated behavior followed by IL2S, as discussed above. Interestingly, Arslan and Ciftci (2021) conducted their study with secondary school learners, while this study was conducted with university students. Previous studies report LE as a strong predictor of intended learning effort for younger learners while IL2S is frequently found to predict intended learning effort of older learners, as reviewed above. Thus, there is a need for further research to explore the role of LE and IL2S in the learners' intended learning effort in the Turkish context with learners of different age and education levels.

It is also found that IL2S was predicted most strongly by instrumentality promotion. This finding supports previous findings that IL2S correlates highly with instrumentality promotion (Taguchi et. al., 2009; Islam, Lamb \& Chambers, 2013). In this study, instrumentality prevention negatively predicted IL2S. Considering the strong correlation between OL2S and instrumentality prevention, the negative regression coefficient of instrumental prevention is not surprising. The findings of this study also support previous findings that OL2S and instrumentality prevention are highly correlated with each other (Papi \& Teimouri, 2012; Busse \& Williams, 2010). Attitudes to learning English, nevertheless, was predicted most strongly by integrativeness and IL2S. This finding can be explained by the interview data about learning experience, as will be discussed below.

The interview data indicate how the L2MSS components influence EFL learners' motivation in the Turkish context. The majority of the interviewees remark that their LE was influential in their motivation. This finding supports the results of the quantitative data, i.e. LE is the strongest predictor of intended learning effort. The interview data, however provide further information on what it is in LE that the learners find valuable. The data point out that the answer to this question in the context of this study is: both the rapport the teachers build with the students and the teachers' individual qualities. This finding lends support to Nakamura's findings (2016) that language learners attributed parental roles to L2 teachers or L2 teachers were regarded as role-models by the learners, and this had a motivating impact on language learning. Interviews also showed that in addition to the teachers, other aspects of LE were important for the learners motivation, i.e. the aspects of novelty, sense of competence and optimal arousal, or lack thereof. The findings in this research suggest that the repetitive nature of the topics covered over the years and lack of progress in communication result in a dramatic decrease in motivation to learn English. Previously, Yetkin and Ekin (2012) reported that in the Turkish secondary school context, there was a steady decrease in the intended learning effort of the participants. The findings of this study suggest that the reason behind such steady decrease over the years is lack of novelty, progress and competence in communication. We believe this is an important finding with serious and fundamental implications for curriculum developers as well as teachers.

Another finding was the interviewees' references to their individual self and relational self in their accounts of their L2 motivation. Seidikes' individual, relational and collective selves (Mercer, 2014) were useful in understanding L2MSS in this study and adopting these constructs can prove to be useful for studies exploring L2MSS. Finally, interview data point out the dynamic interplay of the interviewees' motivational self systems. All interviewees gave accounts of their language learning journeys where initial motivations were transformed to or came to be supported by other motives. Cultural interest and integrative motives came to be connected to the interviewees' ideal selves, as discussed above. Considering the participants' age range, this is hardly surprising. Yet, this finding points the dynamic quality and possible transition of motives during language learning as Mercer (2011) and Dörnyei (2009) suggest.

This study investigated the L2MSS in the Turkish university context. The findings suggest that, like previous research, this framework can explain a great variance in the university students' motivation to learn English in the Turkish tertiary context. The data also support previous research on the relationship 
COURSE \& SAKA - Çukurova Üniversitesi Eğitim Fakültesi Dergisi, 50(2), 2021, 649-662

among components of L2MSS. The findings also point out the significant role both classroom practices and teachers play in the language learners' initial motivation and indicate a dynamic interplay among L2MSS components.

In this study, all rules within the scope of the "Directive on Scientific Research and Publication Ethics of Higher Education Institutions" were followed. None of the actions mentioned under the heading "Actions Contrary to Scientific Research and Publication Ethics", which is the second part of the directive, have been carried out.

\section{References}

Altıner, C. (2018). Preparatory school students' English language learning motivation: A sample from Turkey. Universal Journal of Educational Research, 6(8), 1729-1737. DOI: 10.13189/ujer.2018.060814

Arslan, T. \& Çiftiçi, H. (2021). Second language motivational self system of sixth graders in Turkey: A correlational study. TESOL Journal, 12(1). https://doi.org/10.1002/tesj.518

Busse, V. \& Williams, M. (2010) Why German? Motivation of students studying German at English universities. The Language Learning Journal, 38(1), 67-85

By, H. \& Laohawiriyanon, C. (2019) The L2 motivational self system of low and high achievers in a Cambodian context, PASAA, 57, 67-100

Ceyhan-Bingöl, Z., Akarslan, K. \& Özkan, Y. (2020). An Investigation into motivational self-systems of Turkish English language learners in higher education. Journal of Education and Practice, 11(34), 919.

Csizer, K. \& Kormos, J. (2009). Learning experiences, selves and motivated learning behaviour: A comparative analysis of structural models for Hungarian secondary and university learners of English. In Z. Dörnyei \& E. Ushioda (Eds.) Motivation, Language Identity and the L2 Self (pp. 98-118) Bristol, UK: Multilingual Matters.

Dörnyei, Z. (2007). Research Methods in Applied Linguistics. Oxford, UK: Oxford University Press.

Dörnyei, Z. (2009). The L2 motivational self system. In Z. Dörnyei \& E. Ushioda (Eds.) Motivation, Language Identity and the L2 Self (pp. 9-42) Bristol, UK: Multilingual Matters.

Dörnyei, Z. (2014). Future self-guides and vision. In K. Csizer \& M. Magid (Eds.) The Impact of SelfConcept on Language Learning (pp. 7-18) Bristol, UK: Multilingual Matters.

Gardner, R. C. 1985. Social Psychology and Second Language Learning The Role of Attitudes and Motivation. London: Edward Arnold

Huang, H.-T., Hsu, C.-C. \& Chen, S.-W. (2015) Identification with social role obligations, possible selves, and L2 motivation in foreign language learning. System (51), 28-38.

Islam, M., Lamb, M. \& Chambers, G. (2013). The L2 motivational self system and national interest: A Pakistani perspective. System 41(2), 231-244.

Kormos, J. \& Csizer, K. (2008). Age-related differences in the motivation of learning English as a foreign language: Attitudes, selves, and motivated learning behaviour. Language Learning 58(2), 327-355.

Lamb, M. (2012). A self system perspective on young adolescents' motivation to learn English in urban and rural settings. Language Learning, 62(4), 997-1023. DOI: 10.1111/j.1467-9922.2012.00719.x

Leech, N. L. \& Onwuegbuzie, A. J. (2009). A typology of mixed methods research designs. Quality \& Quantity: International Journal of Methodology, 43(2), 265-275. DOI: 10.1007/s11135-007-9105-3

$\mathrm{Li}, \mathrm{Q}$. (2014). Differences in the motivation of Chinese learners of English in a foreign and second language context. System 46, 451-461.

Markus, H. \& Nurius, P. (1986). Possible selves. American Psychologist. 41(9), 954-969. 
COURSE \& SAKA - Çukurova Üniversitesi Eğitim Fakültesi Dergisi, 50(2), 2021, 649-662

Mercer, S. (2011). Language learner self-concept: Complexity, continuity and change. System 39(3), 335346.

Mercer, S. (2014). Re-imagining the self as a network of relationships. in K. Csizer \& M. Magid (eds.) The Impact of Self-Concept on Language Learning. (pp. 51-69). Bristol, UK: Multilingual Matters.

Moskovsky, C., Racheva, S., Assulaimani, T. \& Harkins, J. (2016). The L2 motivational self system and L2 achievement: a study of Saudi EFL learners. The Modern Language Journal 100(3), 641-654.

Munezane, Y. (2013). Attitudes, affect and ideal L2 self as predictors of willingness to communicate. EUROSLA Yearbook, 13, 176-198

Nakamura, T. (2016). A comparative analysis of Japanese language learners' motivation in Australia and Korea. Innovation in Language Learning and Teaching, 12(4), 316-329, DOI: 10.1080/17501229.2016.1213267

Öz, H. \& Bursalı, N. (2018). The relationship between L2 motivational self-system and willingness to communicate in learning English as a foreign language. Journal of Language and Linguistic Studies, 14(4), 01-11.

Papi, M. (2010). The L2 motivational self system, L2 anxiety, and motivated behaviour: A structural equation modelling approach. System 38(3), 467-479.

Papi, M. \& Teimouri, Y. (2012). Dynamics of selves and motivation: A cross-sectional study in the EFL context of Iran. International Journal of Applied Linguistics 22(3), 287-309.

Peker, H. (2020). Feared L2 self as an emerging component of the reconceptualized L2 motivational self system. Eurasian Journal of Applied Linguistics, 6(3), 361-386, DOI: 10.32601/ejal.834658.

Schoonenboom, J. \& Johnson, R., B. (2017). How to construct a mixed methods research design. Köln Z Soziol 69, 107-131. DOI: 10.1007/s11577-017-0454-1

Taguchi, T., Magid, M. \& Papi, M. (2009). The L2 motivational self system among Japanese, Chienese and Iranian learners of English: A comparative study. In Z. Dörnyei \& E. Ushioda (Eds.) Motivation, Language Identity and the L2 Self (pp. 66-97) Bristol, UK: Multilingual Matters.

Yetkin, R. \& Ekin, S. (2018). Motivational orientations of secondary school EFL learners toward language learning. Eurasian Journal of Applied Linguistics. 4(2), 375-388

Ueki, M. \& Takeuchi, O. (2013). Forming a clearer image of ideal L2 self: the L2 motivational self system and learner autonomy in a Japanese EFL context. Innovation in Language Learning and Teaching. 7(3), 238-252, DOI: 10.1080/17501229.2013.836205

Ushioda, E. (2009). A person-in-context relational view of emergent motivation, self and identity, in Z. Dörnyei \& E. Ushioda (Eds.) Motivation, Language Identity and the L2 Self (pp. 215-228) Bristol, UK: Multilingual Matters.

Weiner, B. (1990). History of motivational research in education. Journal of Educational Psychology. 82(4), 616-622. 